\title{
Replicações da tese do dilema racial brasileiro no âmbito das investigações socioculturais sobre futebol no Brasil
}

http://dx.doi.org/10.11606/1807-5509202000040711

\author{
Juliano de Souza* \\ Wanderley Marchi Júnior ${ }^{* *}$
}

*Universidade Estadual de Maringá, Maringá, PR, Brasil.

**Universidade Federal do Paraná, Curitiba PR, Brasil.

\section{Resumo}

Nesse texto reunimos uma série de análises e discussões que evidenciam a constituição de uma "família intelectual" preponderante no campo dos estudos socioculturais do futebol no Brasil, a saber, aquela que, a par da tese do dilema racial brasileiro, concebeu essa prática esportiva como espaço em que negros e mestiços foram inseridos de forma ambígua e a partir do jugo de avaliações morais heterônomas. Para cumprir esse objetivo, revisitaremos inicialmente alguns aspectos da tese sociológica do dilema racial brasileiro e, na sequência, demonstraremos as replicações desta tese no âmbito das investigações socioculturais sobre futebol no Brasil. Por fim, esboçaremos algumas criticas a essa linhagem no que tange, sobretudo, ao tratamento periférico conferido à variável classe. Em termos de conclusão, ressaltamos que a leitura racialista das relações de desigualdade no contexto futebolístico brasileiro ao se estruturar como resposta à tese da democracia racial, acabou subestimando a dimensão de classe, sendo necessário então um maior investimento científico no sentido de melhor correlacionar essas duas variáveis nas explicações sociológicas sobre o futebol.

Palavras-chave: Futebol; Sociologia do conhecimento; Raça; Classe.

\section{Introdução}

Esse texto recupera parte das investigaçóes empírico-teóricas que foram levadas a cabo na tese de doutorado de um dos autores ${ }^{1}$. Apresentamos aqui, portanto, uma série de análises e discussóes que evidenciam a constituição de uma linhagem ou "família intelectual" preponderante no campo dos estudos socioculturais do futebol no Brasil, a saber, aquela família que, em resposta à tese da democracia racial estruturada no sentido de afirmar o futebol brasileiro como espaço de resolução sui generis de conflitos raciais e sociais ${ }^{1}$, defende justamente o contrário disso e aponta que o futebol é mais um dos espaços históricos desta sociedade, no qual negros e mestiços foram inseridos de forma ambígua e a partir do jugo de avaliações morais heterônomas.

Cabe ressaltar que esse tipo de interpretação encontra fundamento no âmbito das tensóes epistemológicas repercutidas e protagonizadas no entấo emergente campo da Sociologia brasileira, tensóes essas correspondentes às lutas de grupos de observação empírica da sociedade, dando condiçóes, portanto, para que fosse possível insurgir a tese do dilema racial que, conforme procuraremos discorrer e demonstrar empiricamente ao longo do presente artigo, faria eco no âmbito das investigaçóes socioculturais ou, mais precisamente, histórico-sociais sobre o futebol no Brasil.

Trata-se de uma "família intelectual" representativa da produção científica no campo dos estudos sóciohistórico-antropológicos do futebol no Brasil e que partilha do consenso epistemológico de que a distribuição dessa prática esportiva no bojo desta sociedade contemplou diferentes grupos sociais, 
sem que isso significasse ausência de conflitos, sobretudo, de ordem racial. Em outras palavras, e conforme discutiremos nas páginas a seguir, a lógica de distribuição social do futebol ao ponto de se popularizar ou se tornar um esporte de apelo massivo, foi analisado no âmbito dessa linhagem

\section{Método}

Para levar a cabo esse escopo investigativo anunciado, apoiamo-nos no programa teórico que BRANDÃO ${ }^{2}$ sistematizou com vistas a avançar no escavamento das linhagens do pensamento político brasileiro em diálogo com as reflexóes pioneiras de Karl Mannheim no campo da Sociologia do Conhecimento. Revisitamos também de forma ortodoxa os escritos do próprio Mannheim ${ }^{3}$ de modo a considerar, portanto, uma das teses centrais formuladas pelo sociólogo húngaro, qual seja, a de que o indivíduo não pensa de maneira isolada e, muito pelo contrário, "[...] participa no pensar acrescentando-se ao que outros homens pensaram antes dele" (p. 31).

Pautados nesse estatuto teórico-metodológico, procuramos então restituir a lógica de entrelaçamento estabelecida entre as análises dos diferentes especialistas culturais no propósito de fazer valer uma interpretação do futebol brasileiro na qual as dinâmicas de estratificação e mobilidade social dos diferentes grupos no contexto dessa prática esportiva foram explicadas a partir de um peso central atribuído à variável raça. Em termos de mobilizaçâo da literatura para testar nossa hipótese de trabalho, elencamos alguns textos que consideramos paradigmáticos da existência dessa matriz analítica do futebol brasileiro, levando em conta, portanto, conforme aponta BRANDÃO ${ }^{2}$, aqueles textos mais significativos para o empreendimento de restituir a existência de determinadas linhagens de pensamento, porque, afinal, tratam-se de produçôes mais autônomas e com a potencialidade desejada para revelar a natureza socialmente constituída de uma concepção teórica.

Dessa forma, o material empírico que deu suporte a investigação não foi elencado a partir de pelo prisma da estratificação racial, acentuando, entretanto, todas as dificuldades e barreiras que foram impostas aos negros e mulatos ao adentrarem no contexto de ação futebolístico brasileiro, seja na condição ideal-típica de praticantes ou então de consumidores.

uma revisão sistemática da literatura de modo a contemplar a partir de buscadores específicos toda a produção materializada sobre a referida temática em livros, artigos, teses, dissertaçóes, jornais, e assim por diante. Nesse sentido, e em conformidade com o que sugere BRANDÁO ${ }^{2}$, priorizamos como recorte analítico aqueles textos clássicos que, por assim dizer, gestaram essa abordagem racialista acerca da socialização futebolística no país, exemplificando imediatamente algumas vias de rotinização dessa leitura tanto no âmbito acadêmico quanto na esfera jornalística. No que se refere à revisitação de textos produzidos em contextos históricos diferentes, afirmamos a validade desse procedimento no sentido de avaliar e demonstrar a lógica de circulação e rotinização das ideias caras a essa linhagem dos estudos socioculturais do futebol para além do contexto original em que emergiram.

De modo a seguirmos nesse roteiro metodológico apresentado e assim cumprirmos com nosso objetivo, revisitaremos inicialmente alguns aspectos da tese sociológica do dilema racial brasileiro. Para tanto, elegemos a obra $A$ integração do negro na sociedade de classes de autoria de Florestan Fernandes como fio condutor da análise, especialmente por esse texto sintetizar de forma original e exemplar os axiomas que sustentam esta tese. Em seguida, demonstraremos algumas das replicaçóes desta tese no âmbito das investigaçóes socioculturais sobre futebol no Brasil, elencando, e não esgotando, algumas das obras que configuraram casos paradigmáticos de rotinização de ideias relacionadas a essa abordagem. Por fim, esboçaremos algumas críticas a essa linhagem, no que tange, sobretudo, ao tratamento periférico conferido à variável classe em seu esquema explicativo. 


\section{Resultados e Discussão}

\section{A tese sociológica do dilema racial brasileiro}

A tese do dilema racial brasileiro desenvolvida por Florestan Fernandes com base nos seus trabalhos empírico-teóricos dos anos 1950 e nas investigações empíricas levadas a cabo no Brasil meridional por Octavio Ianni e Fernando Henrique Cardoso no início dos anos 1960, é, sem dúvida alguma, uma das críticas mais contundentes direcionadas ao esquema explicativo de Gilberto Freyre e ao mito da democracia racial. Se fôssemos resumir em poucas palavras o principal ponto do argumento de Freyre que tais sociólogos integrantes da denominada Escola Sociológica Paulista não puderam aceitar, diríamos que seria a ausência de uma síntese sem dialética no seu esquema explicativo. Dito de outro modo, e fazendo uso das palavras do próprio FrEYrE ${ }^{4}$, os sociólogos uspianos da década de 1960 rejeitaram, de antemão, o pressuposto de que "[...] dentro desse sistema muita comunicação houve entre casas-grandes e senzalas, entre sobrados e mucambos e não apenas separação ou diferenciação. Síntese e não apenas antítese. Complementação afetiva e não apenas diversificação economicamente antagônica" (p. 55).

Contrário a tal tese, o grupo animado por Fernandes acreditava que, no contexto da sociedade de castas, não poderiam se constituir relaçóes verticais "açucaradas" bem como relaçóes horizontais entre senhores e escravos; tampouco isso era possível no cenário de trabalho livre na sociedade inclusiva. Em outros termos, não se aceitava a concepção fundada no princípio de uma convivência harmônica coexistente ao sistema social ancorado no domínio de exploraçáo capitalista. Além disso, contestava-se o quão significativo para o suposto estabelecimento de uma ordem social democrática seria, de fato, a influência cultural "recíproca" mediada entre brancos e negros num nível de acomodação social em que os primeiros exerciam papéis politicamente dominantes e os segundos, no máximo, cumpriam eficazmente seus papéis de submissos.

A obra paradigmática que sintetiza essas proposiçóes defendidas pela Escola Sociológica Paulista, foi assinada por Florestan Fernandes sob o título: A integração do negro na sociedade de classes. Segundo Fernandes ${ }^{5}$, a referida obra, composta de dois tomos, tratou-se de um trabalho escrito às pressas, entre janeiro de $1963 \mathrm{e}$ abril de 1964, como requisito para uma prova de concurso na qual se pleiteava uma cadeira titular em Sociologia na Universidade de São Paulo.

No primeiro volume que teve como subtítulo O legado da raça branca, o autor procurou (1) deslindar o drama social do negro na transição da ordem escravocrata para uma ordem social competitiva e (2) problematizar a natureza ideológica do mito da democracia racial. Já no volume dois - No limiar de uma nova era -, Fernandes pretendia (1) situar os movimentos sociais negros como perspectiva de tomada de consciência desses setores populacionais quanto às condiçôes históricas de injustiça e opressão a que foram submetidos no Brasil e (2) explicitar, de um ponto de vista histórico, estrutural e psicossocial, como que se constituiu o dilema racial brasileiro.

Ao elencar esses objetivos, Florestan Fernandes, de certo modo, retoma o projeto de Caio Prado Júnior e procura então analisar como que o povo emergiu na história do Brasil, priorizando, para tanto, o desvelamento do drama daqueles setores populacionais que tiveram o pior ponto de partida para a integraçáo ao novo regime social que aqui instituiu-se após a desagregação da ordem escravocrata, quais sejam, negros e mulatos. Em outros termos, em seu estudo sobre a transição de uma sociedade de castas para uma sociedade de classe, Fernandes 5 , se propôs a identificar e situar o peso conferido pelo componente racialista no interior de uma formação econômica e política relativamente nova de maneira a demonstrar que ao homem de cor branca foram possibilitadas melhores condiçóes de adaptaçáo ao novo sistema em emergência e, em contrapartida, ao homem de cor negra essas condiçóes de adaptação, por questóes estruturais e psicossociais que remontam ao próprio período escravocrata, não foram garantidas.

É sempre importante reiterar que, para FERNANDES 5 , o contingente de população negra recém-largada à sua própria sorte foi a que teve o pior ponto de partida nessa nova ordem social competitiva que culminou com o desenvolvimento do sistema capitalista no Brasil, mais especificamente, como dimensionado na cidade de São Paulo - o seu laboratório empírico por justamente se tratar do primeiro centro urbano especialmente burguês do país. Nesse percurso, o autor ainda problematiza as formas intransparentes pelas quais se construiu um sistema que impedia e vetava a ascensão social 
do negro na nova ordem social competitiva, mas sem que, em última instância, tanto os dominadores brancos quanto os dominados tivessem profunda consciência disso.

Ao propor esse tipo de abordagem, Fernandes, colocou categoricamente em xeque as premissas empírico-teóricas que sustentavam as teses acerca da democracia racial. De acordo com o sociólogo paulista, a democracia racial não passava de um mito e como ideologia social perversa cumpria satisfatoriamente o papel de relativizar o drama social do negro na sociedade de classes, favorecendo, dessa forma, a continuidade e reproduçáo do projeto políticosocial dominante'.

Ademais, essa perspectiva de "utilidade" social do mito cumpria-se na medida em que a partir de tal proposta analítica generalizava-se, segundo Fernandes 5 (p. 311), uma concepção em que (1) o drama da "população de cor" era explicado com base na suposta incapacidade ou irresponsabilidade do negro; (2) era relativizada a posição do branco quanto à situação ambígua e marginal ocupada pelo negro nesse tipo de sociedade; e (3) as relaçóes entre brancos e negros eram reduzidas e avaliadas a partir de questôes exteriores (vistas a olho nu) que constituíam um conhecimento imediato do mundo social e davam suporte, portanto, à construção de uma consciência falsa da realidade racial no país.

Inúmeros dados quantitativos e qualitativos foram mobilizados por Fernandes para dar suporte a essa investigação. Aqui nos importa destacar, sobretudo, as histórias de vida de seus informantes registradas em documentos e evocadas categoricamente durante o processo de construção de seu texto em apreço. Na última parte do volume I de seu livro, o sociólogo paulista apresentou entáo sistematicamente uma série de casos que, de um lado, situavam o mito da democracia racial como embuste e, de outro, evidenciavam que as relaçóes entre negros, brancos e mulatos, no contexto da sociedade inclusiva - e do ponto de vista das orientaçóes psicossociais e afetivas que guiavam o comportamento dos agentes -, ainda eram reguladas pelas antigas etiquetas das relaçóes raciais e de dominação tais como constituídas na ordem social de base escravocrata e senhorial. Observemos com mais afinco esse tipo de proposição no relato que segue $e^{5}$ :

Os negros de agora não conhecem mais o seu lugar. São uns malcriados, atrevidos e, às vezes, até desonestos. A A., uma cozinheira que tive, saiu daqui fazendo malcriação, dizendo que negro era melhor que branco, que negro sabe educar filho, que negro não é vagabundo... e uma porção de coisas que nem me lembro! A A. era mulata, era educada, parecia muito fina, mas tinha um "azedume" por causa da cor. Quando ela entrou aqui, disse que havia saído da casa da outra patroa, porque ela era muito orgulhosa, achava que negro não era gente, e que não admitia que o filho dela [dela, A.] entrasse na casa para conversar com a mãe. Tinha que ficar só no portão. Eu disse que não achava isso certo, que ela podia receber o filho no quarto, dar café com pão e mesmo almoço, de vez em quando. Sabe o que aconteceu? Uma vez eu desci para ver uma cesta de costura e sabe o que vi?... O mulatinho de A., refestelado na poltrona da sala de visitas, lendo as revistas, com o pé em cima da mesinha... Nem meus filhos e minhas visitas tomam essa liberdade! Quando eu disse para a A. que ela devia receber o filho só no quarto dela, e náo deixar que ele sentasse ali na sala de visitas, ela ficou furiosa: "É isso mesmo! Diz que náo é igual às outras, só para fingir de boa, mas no fim sáo todas iguais, acham sempre que negro náo é gente!” Mas que desaforo... Entáo uma professora vai sentar na cadeira do diretor do Grupo? Uma enfermeira toma conta, como se fosse seu, do consultório do médico? Cada pessoa tem seu lugar, seu emprego e não vai tomando conta do que não é seu. Mas os pretos, quando a gente trata bem, pensam que são iguais, que podem fazer tudo que querem (p. 336-337, os grifos são nossos).

Sob vários aspectos, depoimentos como esses são centrais e decisivos para a construção das teses de Florestan Fernandes. Primeiramente, a cena é bastante clara quanto à efetiva "comunicação" existente na sociedade de classes entre setores populacionais brancos e negros, sem que, no entanto, essas situações deixassem de ser protagonizadas entre, de um lado, os dominantes e, de outro, os dominados. Além disso, esses papéis sociais, tal como argumentou o sociólogo paulista, eram apreendidos de modo inconsciente e conservavam reminiscências do núcleo de relaçóes psicossociais estruturadas no contexto da sociedade de ordem senhorial brasileira.

Em segundo lugar, esse relato evocado, assim como outros trazidos à tona durante o livro de Fernandes que estamos examinando, permite notar certa tomada de consciência das populaçóes negras e mulatas - representada, no relato aqui em tela, na figura da cozinheira A. - quanto ao contrato social compartilhado entre os brancos no que dizia respeito à posição ou espaço a ser preenchido pelo 
elemento negro e mulato na sociedade inclusiva. No entanto, é importante ressaltar que a atitude aparentemente inconformada da cozinheira mulata, além de estar pautada em uma ética das relações raciais naturalizada, contribuía, por vias imperceptíveis e ocultas, no ato de reforçar o próprio estigma coletivo construído no Brasil com relação às populaçóes de cor.

Nesse contexto, ao pensarmos, por exemplo, com Bourdieu, um dos autores das Ciências Sociais que mais contribuiu para desnaturalizar os discursos de naturalização da desigualdade ao mostrar que a violência simbólica atua por vias inconscientes tanto pelos que a exercem quanto pelos que a sofrem, temos que as dinâmicas de sociabilidade advindas do contrato social misto pós-abolição, mesmo que pudessem sugerir, à primeira vista, avanços nas relaçóes entre brancos e negros na sociedade inclusiva, ainda guardavam reminiscências da ordem social objetivada de violência que historicamente a precedeu, por intermédio, entretanto, da ação de uma violência muito mais sofisticada e branda, tal como analisaremos a seguir ao nos voltarmos para o caso paradigmático do futebol.

Por fim, o trecho supracitado nos permite visualizar algo que Florestan Fernandes se preocupou em demonstrar ao longo de todo o livro, mas que só iria revelar de modo explícito nas últimas páginas do volume, isto é, de que “[...] não foi a imagem negativa ou restritiva do 'preto' que criou a discriminação e o preconceito raciais. Porém o inverso"5 (p. 384). Nesse caso, os padróes de acomodação racial conhecidos na sociedade inclusiva - onde se cristalizara profundas distinções em função da cor dos indivíduos - se explicavam tanto porque os negros e brancos eram provas vivas de que alguns haviam sido senhores e outros escravos durante o regime senhorial, quanto pelo fato dos negros - personagens percebidos negativamente na sociedade inclusiva porque a cor de suas peles era relacionada à vida degradante que levavam, outrora, nas senzalas, lavouras ou mesmo nas casas-grandes - estarem despreparados, do ponto de vista psicossocial, para o ingresso na nova ordem societária emergente.

Em contrapartida, a sociedade paulistana estudada pelo autor, passando por um processo de "revolução burguesa lenta e molecularizada" também não favorecia uma integração mais democrática do negro e do mulato no regime de classes, condenando-o a um destino social ou, melhor dizendo, a uma integração marginal e degradante na sociedade competitiva regulada pelos imperativos do mercado. Neste sentido, é permissível argumentar que Florestan Fernandes pintou seu painel sociológico em $A$ integração do negro na sociedade de classes, levando em consideração a coexistência de dois mundos - o da ordem social e o da ordem racial - mas, sem que o primeiro, absorvesse o último, de modo que a etiqueta das relaçóes raciais, construída no contexto da sociedade escravocrata, permanecia intacta na sociedade inclusiva (ou tão mais severa), impedindo e vetando as possibilidades reais de ascensão social de negros e mulatos como um grupo uniforme ou mesmo diluído no seio das lutas de classe.

\section{Replicações da tese do dilema racial brasileiro nas análises socioculturais sobre futebol}

Avançando no intuito de demonstrar e compreender como que a tese do dilema racial brasileiro se fez circular no campo dos estudos socioculturais sobre futebol no Brasil, é importante frisar que o próprio Florestan Fernandes estava a par do quão contraditório havia sido o processo de inserção dos negros no esporte, tanto que no livro Brancos e negros em Sáo Paulo, o sociólogo paulista, em colaboração com Bastide, menciona situaçóes que remetem ao fato de que negros haviam sofrido censuras na prática de modalidades esportivas como futebol e natação ${ }^{6}$.

Cabe notar que esse tipo de nota, ainda que de forma bastante pontual, também se fez presente no livro A integração do negro na sociedade de classes. Em sua pesquisa empírica que subsidiou a produção do referido livro, Florestan Fernandes apresenta alguns relatos que evidenciam os potenciais entraves e conflitos endêmicos ao processo de absorção do negro no contexto futebolístico nacional. Um desses relatos, diz assim ${ }^{5}$ :

\footnotetext{
Ainda em 1952 pudemos observar a indignação de um luso-brasileiro diante da elevação de L., grande jogador mulato, à condição de técnico do seu clube. $\mathrm{O}$ informante era torcedor fanático daquele clube e achava que seu quadro ia mal em virtude daquela circunstância. "L. é um grande jogador, ainda agora. Mas o mal foi terem-no aproveitado como técnico. [...] Negro não serve para isso. Náo serve para mandar e ainda mais
} 
para mandar em branco. [...] L., como todo preto, é desorganizado e insubordinado. Como poderia entáo ser chefe e dar ordens? Ninguém quis obedecer-lhe e o exemplo de insubordinaçáo tomaram dele próprio. [...] Além disso, no quadro há rapazes brancos, de fina educação, inclusive advogados formados. Como poderiam ser comandados por um negro e receber ordens dele? (p. 348, os grifos são nossos).

De fato, como é possível visualizar nessa passagem, negros e mestiços ainda que incluídos no contexto de açáo futebolístico brasileiro tiveram constantemente que digerir aqueles comportamentos e insinuaçóes preconceituosas por parte dos pares brancos. Mesmo emergindo a posiçôes de comando, nesse caso aludido, a uma posição de técnico de futebol, os indivíduos negros, com as devidas e destacadas exceçóes, quase sempre tiveram suas capacidades colocadas em dúvida, dentre outros fatores, por conta da cor de suas peles. Claro que o exemplo trazido à tona por Florestan Fernandes ao ser pensado em termos exclusivos de futebol se constituiria em um caso à parte, pois como lembra, por exemplo, Tonini ${ }^{7}$, poucos na história foram e têm sido os técnicos, dirigentes e árbitros negros que atuaram no contexto de ação futebolístico brasileiro e até mesmo mundial, com exceção dos países do continente africano.

Não obstante essa condição de excepcionalidade sugerida, quando nos reportamos, do ponto de vista histórico, às relaçóes sociais de contato racial misto, estabelecidas entre quem produz o espetáculo - os jogadores - e quem o assiste nos estádios, esse cenário tende a apresentar mais elementos de regularidade. A propósito, um dos textos que documenta uma ampliação considerável da gama de personagens que sofreram investidas racistas no domínio do futebol brasileiro é datado de 1947 e foi assinado por Mario Rodrigues Filho com o título $O$ negro no futebol brasileiro.

Oportuno destacar que a referida obra foi gestada no contexto de um caloroso debate racialista entâo em voga no Brasil, debate cujo qual Florestan Fernandes ao lado de Roger Bastide fizeram parte no início dos anos 1950, em virtude de suas pesquisas encomendadas e financiadas pela UNESCO no intuito de verificarem se a sociedade brasileira, de fato, era ou não um laboratório sui generis de negociação dos conflitos raciais ${ }^{6}$. Por conseguinte, esse conjunto de reflexóes levadas a cabo pelos autores deu subsídio à produção do livro Relaçôes raciais entre brancos e negros em São Paulo no ano de 1955, obra cuja influência dos argumentos desenvolvidos bem como do material empírico coletado seria importante para os trabalhos posteriores de Florestan Fernandes ${ }^{8}$.

Há que se ressaltar também que Florestan Fernandes, segundo aponta Murad ${ }^{9}$, tinha conhecimento da obra $O$ negro no futebol brasileiro e teceu alguns comentários elogiosos a mesma e ao seu autor, condiçẫo que sugere a hipótese de que o texto de Mario Filho, ou ao menos parte dos episódios narrado no mesmo, foi um marco importante da replicação da tese do dilema racial no campo dos estudos socioculturais sobre futebol no Brasil. Note-se também, em conformidade com SOARES ${ }^{10-11}$, que houve uma relativa mudança de tom com que foram narrados os conflitos racialistas na segunda edição do livro $O$ negro no futebol brasileiro publicada em $1964^{\mathrm{i}}$, situação que sugere uma intimidade mais próxima de Mario Filho com as teses de Florestan Fernandes.

A propósito, uma série de passagens narradas em O negro no futebol brasileiro - em sua quarta edição de 2003 - reiteram o caráter de preocupação de seu autor em ponderar que a inserçáo de negros no contexto de ação futebolístico brasileiro não foi tão pacífica como tendem a atribuir à sua narrativa. Atentemo-nos a alguns desses excertos ${ }^{12}$ :

A grande culpa de Heráclito era ser preto. O Bangu sabia disso, podia aproveitar a ocasiáo para branquear um pouco o time, mas preferiu deixar Heráclito no gol. Por mais algum tempo, até que aparecesse um outro quíper, preto ou branco, feito lá em cima. Melhor branco. Era sempre bom, mesmo para um clube de fábrica ter mais brancos do que pretos no time. Os pretos eram muito visados, quase não podendo fazer nada em campo. Tendo de jogar um futebol muito limpo, muito decente, respeitando os brancos. Quando o preto metia o pé num branco era sururu na certa. Todo mundo achando que preto devia ser posto para fora do campo (p. 88).

Os torcedores do Bangu perdiam-se na geral, na arquibancada, nem abriam a boca. Os pretos que se portassem muito direitinho, senão apanhavam. Até de outros pretos, os pretos da geral, que torciam pelo grande clube, que vinham logo ofendendo com um 'negro sujo' (p. 89).

Só Chiquinho, preto também, não ia para a Praça Sete, não ia para o botequim. Acabado o treino, o jogo, vestia-se, escondido, nada de ficar nu na frente dos outros, dava um 'até amanha' e desaparecia. Um esquisito. Não queria 
saber de noitadas (p. 92).

O Vasco não fazia pretos: para entrar no Vasco tinha de ser já bom jogador. Entre um branco e um preto, os dois jogando a mesma coisa, o Vasco ficava com o Branco. O preto era para a necessidade, para ajudar o Vasco a vencer (p. 120).

A CBD não desconhecia o valor dos Nelson Conceição. Se Nelson Conceiçấo fosse para Buenos Aires os brasileiros seriam chamados de 'maquaquitos' como dois anos antes em Montevidéu. Também o escrete brasileiro levara para Montevidéu mulatos e pretos demais (p. 144).

Os 'arrepiados' faziam a má propaganda dos mulatos e pretos. Havia muito mais 'Arrepiados' do que se imaginava. Por isso a idéia que se tinha dos mulatos e dos pretos dos outros era o pior possível. Era o que explicava tanto mulato querer passar por branco, tanto preto mandar estivar o cabelo para fugir da condenação da marcha de Lamartine Babo, até hoje eternizada nos carnavais. - O teu cabelo não nega! (p. 245).

Relatos como esses se fazem presentes em vários momentos do texto de Mario Filho aqui em apreço e remetem, para além de seus próprios preconceitos náo-objetivados, a alguns dos paradoxos e conflitos inerentes às relaçóes firmadas entre, de um lado, os brancos e, de outro, os negros e mestiços no contexto de ação futebolístico carioca e, de um modo mais amplo, em todo o Brasil. Como é possível notar nos referidos excertos, a etiqueta das relaçóes raciais que se estabelecia tanto entre jogadores quanto torcedores vinculados a essa prática esportiva era conduzida segundo o jugo de avaliações morais heterônomas que colocavam o negro e o mulato em uma posição de constante desconforto e sofrimento, reforçada por preconceitos direcionados às suas pessoas e, muito curiosamente, pela interiorização que negros e mulatos faziam dos clichês impostos a eles mesmos ou entáo pela própria recusa de suas identidades. No tocante a este último fato, é importante frisar que a leitura realizada por MARIO FilHo ${ }^{12}$ revela que uma série de jogadores negros se preocupava em alisar o cabelo (há quem tenha feito até cirurgias plásticas no nariz) em resposta ao tratamento social que recebiam por conta de sua raça, assim como torcedores negros e mulatos procuravam se comportar nos estádios em conformidade com os padróes de etiqueta vislumbrados pelas elites brancas.

Nessa linha de raciocínio, o que se coloca em questáo é o fato de que o negro ao tentar sincronizar seu comportamento ao das classes mais abastadas, tentou absorver um habitus que não fazia parte da sua realidade, pois como sabemos, a herança cultural legada pelo período escravista, não possibilitou que negros vivessem em pé-de-igualdade com brancos. Contudo, essa configuraçáo do campo social não se resumia apenas a questão da hexis corporal ou, melhor dizendo, do contexto racial da cor da pele. Pelo contrário, existia uma série de fatores que contribuíam para essa posiçáo de agentes dominados entre negros, a exemplo da ausência de um capital econômico equivalente ao dos brancos, os baixos níveis de capital cultural, social e, por fim, de capital simbólico. Ou seja, ao interpretarmos esse cenário a partir da abordagem sociológica de Bourdieu, temos que o rebaixamento do negro na sociedade brasileira não estava somente atrelado ao fator raça.

Do que segue a partir dessa proposta de análise, em alguma medida, tematizada a partir de outro registro teórico-conceitual em Florestan Fernandes, é possível afirmar que se reproduziu no contexto futebolístico toda uma mística negativa em relação a jogadores mulatos e negros, colocando em estado permanente de dúvidas o caráter destes agentes e o reconhecimento dos mesmos como seres humanos dignos de respeito e confiança: "Havia quem acreditasse piamente no suborno de jogadores. Principalmente de mulatos e pretos"12 (p. 244). Sob esse pano de fundo teórico, pode-se dizer entáo que no âmbito dos estudos socioculturais sobre futebol que atribuíram um peso central à variável raça para entender as dinâmicas sociais constituídas nesse espaço, existe certo consenso epistemológico de que a ascensão de negros no contexto de ação futebolístico nacional não levou em conta suas potencialidades como seres humanos, a propósito do que ocorreu com aquelas pessoas ajustadas aos padróes éticos e estéticos do sistema social vigente, e, ao invés disso, esteve ancorada em função de suas supostas "habilidades inatas" para a prática deste esporte tal como se convencionou a disseminar a partir, sobretudo, das ideias-força produzidas e defendidas no domínio da linhagem culturalista da Sociologia do Futebol brasileiro ${ }^{1}$.

Em outros termos, os porta-vozes históricos e mesmo os continuadores mais recentes dessa linhagem dos estudos socioculturais do futebol afeita à tese do dilema racial brasileiro, procuram argumentar, tal como o faz, por exemplo, Tonini ${ }^{7}$, que existe uma rede, por vezes velada, de preconceitos e discriminaçôes estabelecidas em função da cor da pele dos indivíduos a atuar no contexto de açáo futebolístico brasileiro desde o momento em que 
o mesmo emergiu até os dias de hoje. E não só contra atletas negros, mas também contra árbitros, treinadores e dirigentes negros. Soma-se a essa leitura, a análise de ABRAHấ ${ }^{13}$, na qual se assinala que a inserção dos negros e mulatos no âmbito do futebol brasileiro, longe de apontar para a inexistência de atos racistas foi e é historicamente atravessada por investidas dessa natureza de modo que tais indivíduos foram incluídos no circuito futebolístico nacional, mas de forma ambígua e quase sempre como alvos de ataques racistas - por meio da violência simbólica - caros aos mais diferentes campos de ação estruturantes desta sociedade.

Diante do que está sendo argumentado, pode-se sustentar, portanto, que, em clara oposição à tese da democracia racial tendencialmente transposta para ler e interpretar algumas das relaçôes protagonizadas no contexto de ação futebolístico brasileiro, uma série de autores que se propuseram a dimensionar as manifestaçôes racistas no futebol nacional se valeram, muitas vezes de forma indireta, da argumentação levada a cabo por Florestan Fernandes no livro $A$ integraçáo do negro na sociedade de classes, sendo, no entanto, a obra $O$ negro no futebol brasileiro de Mario Filho - especificamente em seu formato final de 1964 - o primeiro texto em que a tese sociológica do dilema racial brasileiro se fez circular de forma incisiva para explicar as dinâmicas sociais estruturantes do futebol no país ${ }^{1}$.

Essa filiação introspectiva às ideias de Florestan Fernandes na área dos estudos sócio-históricoantropológicos do futebol brasileiro por via, sobretudo, da interpretação histórico-social que Mario Filho teceria acerca dessa prática esportiva no país e do recrudescimento do racismo tal como delineado nessa esfera de ação, em particular após a derrota do selecionado brasileiro na final da Copa do Mundo de Futebol de 1950 diante do Uruguai e quando entáo três negros foram responsabilizados pelo fato ${ }^{12}$ (p. 16), é passível de ser visualizada, dentre outras possibilidades, no texto "Racismo no futebol brasileiro" de autoria de Lúcia Helena Corrêa ${ }^{14}$. No referido texto, publicado em 1985, a autora argumenta que o racismo que quase linchou o jogador Leônidas em 1932 continuara o mesmo no país. Mais que isso, o investimento racista, segundo $\mathrm{ela}^{14}$, apenas haveria apurado o seu estilo: "Na verdade, tão somente abandonou expressôes como negro sujo e crioulo nojento, repetidas em coro nos estádios dos anos 20 e 30, para abrigar-se em conceitos mais modernos e menos vulgares. Mas nem por isso menos cruéis" (p. 31, grifos no original).
Para CorrêA $A^{14}$, o processo de ascensão do negro no espaço do futebol foi marcado por inúmeros vetos e estratégias subversivas. Uma dessas estratégias, por exemplo, foi a "ginástica do embranquecimento" a que alguns atletas negros foram expostos a ponto mesmo de interiorizarem a visão de mundo dominante $\mathrm{e}$, com respaldo nela, procurarem se enquadrar aos parâmetros estéticos adotados pelos jogadores brancos. É o caso, por exemplo, do que aconteceu durante os anos 1910 a 1930 com Arthur Friedenreich, talvez o primeiro negro a alcançar projeção no futebol nacional e que: “[...] sempre chegava atrasado aos jogos, preso nos vestiários, tentando alisar a farta carapinha à custa de muita goma arábica"13 (p. 36).

De acordo com a autora ${ }^{14}$, essas situaçóes, ainda que sob outras roupagens, foram sendo recorrentes na história do futebol brasileiro. Um exemplo disso, foi a composição do selecionado de futebol nacional em 1984 que contava com apenas três negros. Além disso, na medida em que o futebol passou a se tornar um espaço mais sensível ao poder econômico e às trocas mercantis, mais uma vez o negro "sobrou", tendo em vista uma série de barreiras de teor econômico que se interpunham à inserção de meninos negros nas escolinhas dos grandes clubes como também ao padrão salarial dos jogadores negros (p. 38-39).

$\mathrm{Na}$ esteira de uma abordagem similar, todavia muito mais complexa, à ensaiada por CoRrÊA ${ }^{14}$, José Jairo VIeIRA ${ }^{15}$ também discutiu alguns critérios de desigualdade que marcaram e têm marcado a inserção de negros e pardos no contexto futebolístico brasileiro. Cabe ressaltar que esse autor, embora tenha mobilizado toda uma literatura internacional sobre racismo no esporte para explicar e problematizar o preconceito e a discriminação racial preponderantes no âmbito futebolístico brasileiro - e, além disso, tenha sido orientado pelo sociólogo Carlos Hasenbalg que, conforme MоттA ${ }^{16}$, estruturou uma análise das relaçôes raciais no Brasil destoante da abordagem da Escola Sociológica Paulista -, ainda assim não deixou de edificar uma interpretação do futebol que, sob vários eixos analíticos, se assemelha à leitura sociológica das relaçóes raciais no Brasil tal como pensada por Fernandes e repercutida no âmbito das investigaçóes socioculturais sobre o futebol no país através dos esforços de Mario Filho em apontar os dilemas que permearam a ascensão do negro nessa prática esportiva.

Uma evidência disso que estamos sugerindo se constitui na medida em que retomamos então o 
texto do pesquisador José Jairo VIEIRA ${ }^{15}$ publicado com o título Consideraçóes sobre preconceito $e$ discriminação racial no futebol brasileiro" na Revista Teoria e Pesquisa tendo como base a abordagem empreendida durante sua tese de doutorado ${ }^{17}$, e constatamos que a discussão ensejada no manuscrito é fomentada a partir de uma série de dados quantitativos e qualitativos que comprovariam que a mobilidade social dos negros e pardos no contexto futebolístico brasileiro e, especificamente, carioca, se daria de uma forma tendencialmente marcada por desigualdades e, portanto, por discriminaçóes quando comparados então à trajetória dos jogadores brancos constituída no bojo dessa mesma prática esportiva ${ }^{15}$.

$\mathrm{O}$ autor, além disso, se propôs na ocasião a desconstruir alguns mitos referentes à participação de negros e pardos no futebol brasileiro, entre os quais de que os jogadores negros e mestiços encontrariam no futebol uma via de ascensão social privilegiada. Para comprovar essa hipótese, Vieira evocou uma série de variáveis expressas através de tabelas e que, grosso modo, sinalizavam para o fato de que os jogadores negros e pardos representariam dentro de sua amostragem - a saber, o futebol carioca em suas três divisóes - o contingente maior de atletas inseridos nessa prática esportiva, mas, em contrapartida com salários menores quando comparados aos jogadores brancos. Para VieIrA ${ }^{15}$, a presença maciça de negros e pardos no futebol carioca não seria sinônimo direto de mobilidade racial e, ao invés disso, este fato, pelo que tudo indica, se apresentaria como um indicativo de que os indivíduos brancos poderiam talvez estar optando por outras ocupaçóes que não a de jogador de futebol. Outra possibilidade que explicaria esse fato é aventada pelo próprio VIEIRA ${ }^{15}$ nos seguintes termos:

O grande contingente de jogadores negros e pardos no
futebol certamente relaciona-se com a não exigência de
qualificaçóes pessoais, tais como formaçáo educacional
ou recursos econômicos, para o ingresso nesta atividade
profissional. Na verdade, as qualificaçóes requeridas
relacionam-se apenas com a própria capacidade de
desempenho no futebol, tais como: resistência, força,
velocidade, visão de jogo e, sobretudo, habilidade com a
bola. Por terem habilidades físicas, o aspecto econômico a
priori náo assume o caráter eliminatório que costuma ter
em outros ramos profissionais que oferecerem situaçóes
similares de prestígio e status (p. 229, os grifos são nossos).

Tal como passível abstrair do excerto, a presença de negros e pardos no contexto de ação futebolístico estudado pelo autor em tela não evidenciaria em si uma suposta natureza democrática das relaçóes constituídas nesse espaço, posto que a inserção de atletas negros e mestiços no âmbito do futebol carioca teria a ver antes com a baixa qualificação profissional exigida por esse esporte do que com uma necessária valorização desses atletas como pessoas importantes e, portanto, merecedoras de estar nesse espaço. No referido trecho, também acaba ficando subjacente a ideia de que o componente racialista não atuaria sozinho no propósito de tornar concreto o processo de inclusão ambígua de negros e mestiços no futebol. Pelo contrário, ao lado da variável racial, ou talvez antes dela, teríamos a variável classe a atuar no sentido de tornar possível o processo pelo qual as populaçóes de cor foram sendo absorvidas, no decorrer da história, no contexto de ação futebolístico nacional, mas sem que isso representasse ganhos objetivos para elas. É ao exame desta dinâmica que nos dedicaremos a partir de agora.

\section{Existe algo para além da variável raça?}

$\mathrm{O}$ acordo epistemológico firmado no âmbito desta "família intelectual" dos estudos socioculturais do futebol no Brasil, tal como acabamos de expor, transcende a narrativa histórica de que a inserção de negros e mulatos no contexto futebolístico brasileiro seria um sintoma de democracia racial. Rompendo, de antemão, com essa análise, tal linhagem partilha do entendimento de que vem havendo uma exclusão velada e, por isso mesmo, tão mais eficaz de determinados segmentos sociais dos principais papéis e postos considerados de destaque na sociedade, condição que se traduziu também no âmbito do futebol.

Esse tipo de diagnose, por conseguinte, nos permite considerar que na medida em que essa prática esportiva dava conta de refletir o ethos de determinado grupo e assegurar ao mesmo os seus elementos distintivos tão importantes na competição social, a participação das populaçóes de cor nesse espaço foi vista como um problema, ao passo que na medida em que o futebol passou por um processo de massificação e tendencialmente perdia o seu poder de expressar a condição simbólica de superioridade das elites brancas, os negros e mestiços já faziam uso dessa prática sem tantos vetos objetivos, porém de forma ambígua e a partir de um processo de absorção que, visto pelo prisma da tese do dilema racial brasileiro, poderia ser sintetizado no termo 
“inclusão discriminatória”.

Por conseguinte, essa proposta de interpretação teórica trazida à tona no âmbito desta "família intelectual", apesar de reveladora, requer ser matizada à luz dos conflitos de classe de modo a náo se conferir um peso excessivo ao componente racialista e, assim, explicar de maneira unilateral uma "inclusão discriminatória" que é sintomática e devedora à combinação de uma série de fatores ${ }^{1}$.

Há que destinar, portanto, um devido valor heurístico às contribuições tecidas pelos portavozes dessa linhagem dos estudos socioculturais do futebol no Brasil, muito embora se reconheça, em conformidade com Jessé SouzA ${ }^{18-19}$, que a abissal desigualdade brasileira não tem origem e não se explica em função da cor da pele dos indivíduos tal como pressuponha Florestan Fernandes em algumas passagens de seu livro $A$ integraçâo do negro na sociedade de classes, apesar do mesmo perceber e enumerar as precondiçóes sociais independentes $\mathrm{da}$ cor que condicionavam a situação de marginalidade deste grupo. Conforme adverte SouzA ${ }^{18-20-21}$, no contexto da sociedade competitiva, a cor dos indivíduos agia no máximo como uma ferida adicional à autoestima desses sujeitos, sendo as razóes últimas de sua marginalização a combinação do abandono e inadaptação sob a forma eternizada de um habitus precário ${ }^{\mathrm{ii}}$ reproduzido cotidianamente.

Frente a esse cenário, a argumentação de SOARES $^{22}$ de que talvez seja mais produtivo explicar as tensões entre atletas, clubes e associações no processo de construção de uma história do futebol brasileiro não à luz tão somente do racismo, mas também das próprias disputas do amadorismo contra o profissionalismo e a partir da dinâmica das instituições esportivas, é esclarecedora, se bem que, a exemplo do discutido e rediscutido episódio envolvendo a criação da Associação Metropolitana de Esportes Atléticos (AMEA) - liga de futebol carioca criada, segundo a versão de MARIO FILHO ${ }^{12}$, como resposta à conquista do campeonato estadual pela equipe vascaína então formada por um time de negros, mestiços e pobres em 1923, e da qual o Vasco acabou não participando - o que nos parece estar em jogo junto à preservação dos códigos amadores do esporte é o interesse de uma classe dominante em não permitir que estratos sociais considerados inferiores viessem a afetar a lógica de distinção que procuravam assegurar com essa prática esportiva.

É sempre importante frisar que essa perspectiva de apreciação teórica proposta, não implica em negar que existiu e ainda existe uma rede de preconceitos e estigmas atuando de forma eficaz e durável na sociedade brasileira com relação a determinados grupos sociais e étnicos nas mais diferentes esferas. $\mathrm{O}$ que ocorre, tal como argumenta Jessé SouzA ${ }^{19}$, é que,

[...] se há preconceito neste terreno, e certamente há e agindo de forma intransparente e virulenta, não é, antes de tudo, um preconceito de cor, mas sim um preconceito que se refere a certo tipo de 'personalidade', julgada como improdutiva e disruptiva para a sociedade como um todo" (p. 58) iii. $^{\mathrm{ii}}$

Nesse particular, é no mínimo razoável considerarse a hipótese de que o que, em primeira instância, explicaria a integração marginal e conflitiva de negros e mestiços, quer como produtores, quer como espectadores no contexto de ação futebolístico brasileiro, não seria a cor da pele, mas a pertença desses indivíduos às suas respectivas classes sociais. Se analisarmos a fundo, inclusive, uma série de fatos descritos e discutidos por Mario Filho em $O$ negro no futebol brasileiro, especialmente nos dois primeiros capítulos do livro, é possível perceber que este autor, ele próprio talvez colocado em dúvida pelas situaçóes que lhe aprouve retratar, chama atenção muito mais para uma série de conflitos psicossociais estabelecidos no futebol brasileiro em função de uma "realidade de classe" do que propriamente uma "realidade de cor". Os vários trechos que seguem autorizam essa leitura e apontam para uma possibilidade alternativa de interpretação deste livro de Mario Filho ${ }^{12}$ :

O operário que jogava ao lado dos mestres, branco ou preto, não subia, não descia, ficava onde estava. Se quisesse subir tinha de trabalhar muito, de aprender muito de passar de teceláo a mestre. Como Francisco Carregal acabaria passando à custa de trabalho, e não de futebol. O futebol era divertimento. Como todo divertimento custava dinheiro. Mais ou menos. Menos em Bangu do que na Rua Retiro de Guanabara, onde o Fluminense fizera o seu campo. Por isso não havia o perigo de que um Francisco Carregal, apesar de mulato limpo, ou um Manuel Maia, apesar de bom preto, respeitador, entrasse no Fluminense (p. 34).

Se Joaquin Prado, winger-left do Paulistano, quer dizer, extrema-esquerda, preto, do ramo preto da família Prado, se transferisse para o Rio, seria recebido de braços abertos no Fluminense. Joaquim Prado era preto, mas era de família ilustre, rico, vivia nas melhores rodas (p. 36). A tendência natural das coisas, cada jogador procurava o seu meio, indo para onde estava sua gente. E quando a 
sua gente não tinha clube, o jeito era fundar mais um (p. 37).

Assim se via melhor a diferença que havia, não entre brancos e pretos, entre clubes. Clubes de bairros, de subúrbios, da zona sul e da zona norte. Grande e pequenos, cada um ficando no seu lugar, conservando as distâncias. Sem tentar nem se aproximar. Às vezes um ao lado do outro, o Fluminense e o Guanabara. O Guanabara no morro, da favela, o Fluminense cá de baixo, do bairro chique. Quem morava na casa de lata ia para o Guanabara, quem morava no Palacete ia para o Fluminense (p. 41).

No fundo, luta de classes, sem ninguém dar por isso, é claro. Todos levando a coisa mais para a rivalidade entre o clube do subúrbio e o clube da cidade. Rivalidade que se acentuava de um lado só, do lado do clube do subúrbio. O clube do subúrbio se afastando, ficando cada vez mais longe, querendo até se separar. Separar por quê? Porque se sentia outro clube, outra gente (p. 43).

Um mulato, um preto podia torcer pelo Fluminense. Havia lugar, na geral, para o mulato, o preto. E para o branco pobre. Mas o branco pobre, o mulato, o preto que torciam pelo Fluminense, procuravam 'ser' Fluminense, distinguindo-se dos torcedores dos outros clubes, caprichando no modo de trajar, vestindo a roupa dos domingos (p. 62).

O amadorismo, o esporte pelo esporte, era para quem estava de cima. Enquanto houvesse o amadorismo os brancos seriam superiores aos pretos, os ricos aos pobres (p. 129).

A distinção que se estabeleceu entre a Amea e a Liga Metropolitana foi esta: uma, liga de brancos, a outra, liga de clubes de brancos, mulatos e negros, tudo misturado (p. 133).

Tais fatos elencados são no mínimo ilustrativos de que este autor não estava alheio aos conflitos de classe que se estabeleceram no futebol brasileiro desde que aqui o mesmo começou a ser praticado, consumido e noticiado. Longe, portanto, de apresentar uma interpretaçáo racialista homogênea do futebol brasileiro, o autor aponta para tendências de estratificação e mobilidade social que também vieram a ser constituídas em função da pertença dos agentes às suas respectivas classes, se bem que a ênfase na realidade racial foi a que prevaleceu, muito embora o próprio Mario Filho não deixasse de ressaltar que tanto a inclusão quanto a exclusão dos indivíduos no contexto de ação futebolístico brasileiro transcendia a dimensão da raça ou ainda que por trás do aspecto racial escondiam-se outros componentes, como, por exemplo, a filiação dos agentes a grupos sociais antagônicos e rivais na competiçáo social ${ }^{1}$.

Ao que parece, a participação dos brancos pobres e de imigrantes pobres na construção da história do futebol brasileiro se constituiu como um contra-processo social decisivo que, em medida considerável, Mario Filho levou visivelmente em conta ao redigir $O$ negro no futebol brasileiro. Esses dois grupos referenciados, nesse sentido, funcionaram como uma "sombra", uma espécie de "segunda voz", na argumentação de Mário Filho, de modo que o autor sentia a necessidade de, sempre que possível, estar se reportando a estes dois segmentos populacionais que, pelo que tudo indica, não eram uma exceçáo à regra na narrativa histórica que lhe aprouve estruturar. Por sua vez, esse tipo de contra-processo sugerido sinaliza para uma confusão potencial no argumento de MARIo FILHO $^{12}$ entre as variáveis raça e classe, na medida em que o autor, ainda que atento às experiências classistas dos agentes, não tinha em claro a forma com que esses dois componentes interagiam e concorriam nas dinâmicas de socialização que the competiu trazer à tona.

Não éo caso, no entanto, de responsabilizar a Mario Filho ou qualquer outro especialista cultural por essas confusóes conceituais que eram retroalimentadas pelo próprio contexto histórico em que tais produtores estavam inseridos, e nem mesmo era o esclarecimento dessas tensóes que competia ao métier desses agentes. Até os dias de hoje, inclusive, estamos longe de chegar a uma solução teórica para esses embatesiv - e a discussão das políticas de cotas é um dos indícios disso - de modo que a variável racial ainda continua se sobrepondo à variável de classe em uma série de explicaçôes academicamente fundamentadas sobre a desigualdade brasileira, na esfera do debate público acerca da desigualdade e mesmo na implementaçáo de políticas inclusivas para corrigir ou, no mínimo, amenizar esse quadro explicitado.

Por sinal, a atualidade dessas polêmicas em torno da sobreposição da variável raça à variável classe nas explicaçôes acionadas na esfera do debate público sobre a estruturação do futebol como espaço excludente e hostil, pode ser dimensionada em uma reportagem que circulou no jornal inglês The Guardian no dia $1^{\circ}$ de julho de $2014^{23}$, em pleno momento em que estava sendo disputada a Copa do Mundo FIFA no país. Tal reportagem de autoria de Felipe Araujo, um jornalista brasileiro naturalizado inglês, girou basicamente em torno da 
problematização de duas questôes: (1) Por que não houve uma quantidade expressiva de negros assistindo in loco a Copa do Mundo da FIFA no Brasil em 2014? (2) Por que jogadores do passado e do presente do futebol brasileiro hesitaram e hesitam em se reconhecerem como negros e desconversaram/desconversam a existência de racismo em relação às suas pessoas, seja dentro ou mesmo fora dos gramados ${ }^{23}$ ?

Ambas as questóes que percorrem o texto publicado no The Guardian, ainda que não devidamente respondidas pelo seu enunciador, são sugestivas do quanto o debate racialista historicamente sistematizado e evocado pela intelectualidade brasileira para responder às dinâmicas de estratificação e mobilidade social no país se fazem incidir sobre a leitura do futebol, especialmente aquelas leituras realizadas por produtores culturais mais autônomos e com um mínimo grau de sensibilidade ao menos para colocarem esse tipo de problema. Essa relativa sensibilidade analítica do autor da matéria em questão, se expressa, por exemplo, na indagação abaixo situada e na resposta que imediatamente apresenta a ela:

So, in a piece of land where $60 \%$ of the population is black or mixed, why then, during one of the most important single events in its history, is the absence of those $60 \%$ so conspicuous? The answer is as obvious as it is tragic. Most black people in Brazil are poor. Unlike in South Africa or the United States, there's no black middle class, and perhaps most importantly there isn't a black political class ${ }^{23, v}$.

De fato, Araujo ${ }^{23}$ nesse trecho de sua intervenção no The Guardian foi certeiro em reconhecer que a ausência de negros nos estádios durante a Copa do Mundo da FIFA no Brasil em 2014 teve a ver com a dimensão da classe social de tais agentes. Em que pese, no entanto, o mérito dessa análise preliminar, em outros momentos de sua reportagem, tal jornalista acabou reforçando, talvez no intuito de rechaçar de maneira imediatista a tese da democracia racial brasileira, que o preconceito e a desigualdade expressa na ausência de negros residentes no Brasil nos estádios em que esteve presente durante a realização da Copa da FIFA de 2014 foram consequências de uma lógica de estratificação social estruturada prioritariamente em torno da questão racial. Ao finalizar sua análise sobre os preconceitos enraizados na sociedade brasileira com relação aos negros e tentar estabelecer um paralelo entre o acesso dessa população aos jogos da Copa da FIFA e as políticas de cotas raciais implantadas no Brasil, o autor ${ }^{23}$ comenta:
However, for all the things this World Cup has provided, opportunities for its black population isn't one of them. On this particular issue Brazil has scored an own goalvi.

Cabe ressaltar que essa sobreposição do componente racial à dimensão do habitus de classe nessas explicaçóes, de teor acadêmico ou não, em relação às causas que estruturariam a desigualdade e preconceito nas diferentes esferas sociais que compóem a sociedade brasileira, inclusive a esportiva, em geral, e a futebolística, em específico, em alguma medida, talvez tenha a ver, de acordo com Jessé SouzA ${ }^{19}$, ao fato de que ao ser rejeitado por alguns setores da intelectualidade brasileira a explicação economicista de classe dada à desigualdade social pela teoria marxista se rejeitou, por extensão, a própria centralidade dessa categoria analítica para avançar no esclarecimento das causas não-econômicas que condicionam a desigualdade no país. Daí, dentre outras coisas, o prestígio acadêmico e social que foi e ainda tem sido conferido à dimensão racial para justificar e mesmo explicar os principais conflitos preponderantes nessa sociedade. Claro que esse problema epistemológico e ao mesmo tempo social não é trazido à tona com vistas a relativizar o preconceito racial atuante no país, mas somente em demonstrar que o prestígio analítico dado à variável raça se legitima a partir do obscurecimento da variável classe em sua acepçáo sociocultural. Nos termos de Jessé SouzA ${ }^{19}$ :

[...] ainda que a cor da pele seja um dado secundário, no caso específico da formação social brasileira, em relação ao habitus de classe, isso obviamente, não significa dizer que o preconceito racial náo exista ou que seja de pouca importância. Significa apenas que é a invisibilidade dos aspectos culturais e simbólicos do "racismo de classe", precisamente por aqueles autores que "compram" o conceito economicista de classe do marxismo e se tornam marxistas sem o saber, que torna a "raça" a única dimensão onde a dominação simbólica e cultural é tornada visível. Essa visibilidade da "raça" é conquistada pela invisibilidade da "classe" como dimensão cultural e simbólica de natureza não-econômica (p. 90 ${ }^{19}$.

Os efeitos ideológicos dessa confusão firmada entre o peso conferido às variáveis raça e classe na compreensão das dinâmicas sociais estruturantes desta sociedade, muito embora se façam sentir com maior intensidade no campo dos estudos acerca da desigualdade, também incidem sobre outras áreas investigativas. No que diz respeito ao campo dos 
estudos sócio-histórico-antropológicos do futebol, pudemos perceber que a ênfase nesses aspectos racialistas se deu com um duplo propósito. Por um lado, não podemos perder de vista que a tese da democracia racial repercutiu no âmbito dos estudos socioculturais do futebol de modo a tornar legítima a noção de "futebol-arte" e permitir a leitura dessa prática esportiva como instituição genuinamente brasileira ${ }^{1}$.

Por outro lado, observamos que em resposta a essa leitura culturalista, a tese do dilema racial brasileiro foi replicada no âmbito das pesquisas socioculturais do futebol no Brasil com o intuito principal de demonstrar que a inserção de negros e mestiços nessa prática esportiva foi conduzida através do jugo de avaliações morais heterônomas e a partir de uma infinidade de clichês e preconceitos. Ao superestimar, no entanto, o componente racialista na análise que se propôs a edificar e ao conceber as populaçóes de cor como dotadas de "virtudes ambíguas" que pouco concorriam para sua melhor inserção no contexto da sociedade inclusiva, essa "família intelectual" dos estudos socioculturais do futebol no Brasil acabou, em certo sentido, se tornando cúmplice no reforço da principal ideologia veiculada na linhagem culturalista preponderante nesse campo investigativo, de modo a corroborar com a ideia de que os negros foram agentes que "abrasileiraram" o "esporte bretão", transformando-o em uma prática puramente nacional ${ }^{1}$.

Como última observação, ressaltamos que nosso intuito nesse texto foi mais fazer uma diagnose do campo dos estudos socioculturais do futebol do que propriamente encontrar ou estabelecer respostas para superar o problema das leituras superestimadas das questōes raciais no esporte. Ademais, acreditamos que a tese do dilema racial brasileiro ao se rotinizar no campo acadêmico, foi legitimada como componente decisivo de análise, o que contribuiu para intensificar as investigaçóes racialistas do futebol, obliterando, em alguma medida, fatores não vinculados à variável raça. Nesse sentido, ao mobilizar apenas as lentes de investigação racial para a leitura do campo, outros fatores ficaram em segundo plano, embora, em determinados contextos, esses aspectos fossem, na verdade, mais influentes do que o elemento racial. Se essa diagnose é verdadeira, novos desafios analíticos se impóem, sendo necessário então um maior investimento científico no sentido de melhor correlacionar as variáveis raça e classe nas explicaçóes sociológicas sobre o futebol.

\section{Notas}

i. Segundo SoAres ${ }^{11}$ (p. 126), a primeira versão do livro O negro no futebol brasileiro continha algumas passagens que remetiam ao poder democrático e ao fim do racismo no futebol brasileiro, passagens essas, segundo o autor, suprimidas da versão de 1964. Independente deste fato, no entanto, entendemos que o referido texto de Mario Rodrigues Filho no que versa ao entendimento e tratamento das relaçóes raciais tal como estruturadas no contexto de ação futebolístico brasileiro não era unilateral e monolítico, muito embora a matriz democratizante tenha se feito prevalecer ao longo de seu livro ${ }^{1}$.

ii. Em linhas bastantes gerais, o habitus precário se refere a uma disposição para ação - no sentido com que essa noção é evocada nos estudos de Bourdieu - que explicaria o destino social trágico marcado pelo abandono e pelo desprezo a que é submetida uma parcela considerável das populaçóes que integram as denominadas sociedades periféricas, no caso do Brasil, mais precisamente, a denominada "ralé" brasileira. Para maior aprofundamento teórico, consultar respectivamente os trabalhos de Jessé Souza realizado sobre a "ralé" e sobre os batalhadores brasileiros ${ }^{20-21}$.

iii. Segundo Jessé SouzA ${ }^{18}$ (p. 160), a confusão estabelecida entre a cor da pele dos indivíduos e a dimensão do habitus de classe, com frequência, seria potencializada por conta de posiçóes políticas tendentes a interpretar que a atribuição da marginalidade do negro a outros fatores, que não a cor da pele e o racismo, equivaleria, por extensão, em infligir a culpa desta situação à própria vítima, ou seja, aos negros e mestiços.

iv. Elementos importantes para aprofundar a discussão sobre o debate racialista na sociedade brasileira podem ser encontrados em: Schwarcz LM. O Espetáculo das Raças: Cientistas, instituiçóes e questão racial no Brasil 18701930. São Paulo: Companhia das Letras; 1993 e em Mota CG. Ideologia da Cultura Brasileira, 1933-1974. São Paulo: Editorial Ática; 1994.

v. Então, em um pedaço de terra onde $60 \%$ da população é negra ou miscigenada, por que a ausência desses $60 \%$ em um dos mais importantes eventos da história é tấo grave? A resposta é tão óbvia quanto trágica. A maioria das 
Souza J , et al.

pessoas negras no Brasil é pobre. Diferentemente da África do Sul e dos Estados Unidos, não há uma classe média negra, e talvez o mais importante, não há uma classe política negra (tradução livre).

vi. No entanto, de todas as coisas que esta Copa do Mundo ofereceu, oportunidades para a população negra não estâo entre elas. Nessa questão em particular, o Brasil marcou um gol contra (tradução livre).

\begin{abstract}
Replications of the thesis of the Brazilian racial dilemma in of sociocultural investigations on soccer in Brazil.

In this text we have gathered a series of analyzes and discussions that show the constitution of a preponderant "intellectual family" in the field of sociocultural studies of soccer in Brazil, namely, that, along with the thesis of the Brazilian racial dilemma, conceived this sport as space in which blacks and mestizos were inserted ambiguously and from the yoke of heteronomous moral evaluations. In order to fulfill this objective, we will initially revisit some aspects of the sociological thesis of the Brazilian racial dilemma and, in the sequence, we will demonstrate the replications of this thesis in the scope of sociocultural investigations on soccer in Brazil. Finally, we will sketch some criticisms of this lineage, especially regarding the peripheral treatment given to the class variable. In terms of conclusion, we emphasize that the racialist reading of inequality relations in the Brazilian football context, when structured as a response to the racial democracy thesis, eventually underestimated the class dimension, requiring a greater scientific investment in order to better correlate these two variables in the sociological explanations about soccer.
\end{abstract}

KEYWORDs: Soccer; Sociology of Knowledge; Race; Class.

\title{
Referências
}

1. Souza J. O "esporte das multidóes" no Brasil: entre o contexto de ação futebolístico e a negociação mimética dos conflitos sociais [tese]. Curitiba (PR): Universidade Federal do Paraná, Programa de Pós-Graduação em Educação Física; 2014.

2. Brandão GMB. Linhagens do pensamento político brasileiro. Dados. 2005;48,2:231-269.

3. Mannheim K. Ideologia e utopia. 3. ed. Rio de Janeiro: Zahar; 1976.

4. Freyre G. Sobrados e Mucambos. 14. ed. São Paulo: Editora Global; 2003.

5. Fernandes F. A integração do negro na sociedade de classes - o legado da "raça branca". 5. ed. São Paulo: Editora Globo; 2008.

6. Bastide R, Fernandes F. Brancos e Negros em São Paulo. 4 ed. São Paulo, Global; 2008.

7. Tonini MD. Além dos gramados: história oral da vida de negros no futebol brasileiro (1970-2010) [dissertação]. São Paulo (SP): Universidade de São Paulo, Programa de Pós-Graduação em História Social; 2010.

8. Bastos ER. O pensamento social da escola sociológica paulista. In: Miceli S, organizador. O que ler na Ciência Social Brasileira (1970-2002). São Paulo: Editora Sumaré; Anpocs/Brasília: Capes; 2002, p. 183-230.

9. Murad M. Consideraçóes possíveis de uma resposta necessária. Revista Estudos Históricos. 1999;13,24:431-446. 10. Soares AJG. Futebol, raça e nacionalidade no Brasil: releitura da história oficial [tese]. Rio de Janeiro (RJ): Universidade Gama Filho, Programa de Pós-Graduação em Educação Física; 1998.

11. Soares AJG. História e invenção das tradiçôes no campo do futebol. Rev Estudos Históricos. 1999a;13,23:119146.

12. Rodrigues Filho M. O negro no futebol brasileiro. 4. ed. Rio de Janeiro: Mauad; 2003.

13. Abrahão BOL. O "preconceito de marca" e a ambigüidade do "racismo à brasileira" no futebol [tese]. Rio de Janeiro (RJ): Universidade Gama Filho, Programa de Pós-Graduação em Educação Física; 2010.

14. Corrêa LH. Racismo no futebol brasileiro. In: Dieguez GK, organizador. Esporte e poder. Petrópolis: Vozes;

724 • Rev Bras Educ Fís Esporte, (São Paulo) 2020 Out-Dez;34(4):711-25 
1985, p. 31-39.

15. Vieira JJ. Consideraçóes sobre o preconceito e discriminação racial no futebol brasileiro. Teoria Pesq. 2003;4243:221-244.

16. Motta R. Paradigmas de interpretação das relaçóes raciais no Brasil. Estudos Afro-Asiáticos. 2000;38:113-133. 17. Vieira JJ. Paixão nacional e mito social: a participação do negro no futebol, profissionalização e ascensão social [tese]. Rio de Janeiro (RJ): IUPERJ, Programa de Pós-Graduação em Sociologia; 2001.

18. Souza JF. A construção social da subcidadania: para uma sociológica política da modernidade periférica. Belo Horizonte: Editora da UFMG; Rio de Janeiro: Iuperj; 2003.

19. Souza JF. A invisibilidade da desigualdade brasileira. Belo Horizonte: Editora da UFMG; 2006.

20. Souza JF. A ralé brasileira: quem é e como vive. Belo Horizonte: Editora da UFMG ;2009.

21. Souza JF. Os batalhadores brasileiros: nova classe média ou nova classe trabalhadora? Belo Horizonte: Editora da UFMG; 2010.

22. Soares AJG. O racismo no futebol do Rio de Janeiro nos anos 20: uma história de identidade. Rev Paulista Educ Física. 1999b;13(1):119-129.

23. Araujo F. The lack of black faces in the crowds shows Brazil is no true rainbow nation. The Guardian, London, 01 de julho de 2014. Disponível em: <http://www.theguardian.com/commentisfree/2014/jul/01/brazil-black-facescrowd-rainbow-nation-world-cup>. Acesso 03 jul. 2014.

\begin{tabular}{|c|c|}
\hline ENDEREÇO & \\
\hline $\begin{array}{r}\text { Juliano de Souza } \\
\text { Universidade Estadual de Marincá }\end{array}$ & Submetido: 10/ 12/ 2016 \\
\hline Av. Colombo, 5790 & Revisado: 31/ 03/2018 \\
\hline $\begin{array}{l}\text { 87020-900 - Maringá - PR - Brasil } \\
\text { E-mail: julianoedf@yahoo.com.br }\end{array}$ & Aceito: 11/07/ 2018 \\
\hline
\end{tabular}

